\title{
The Equation of Brain Death with Legal Death in Islamic Law: A Critical Appraisal
}

\author{
Dr.Sayed Sikandar Shah Haneef \\ Professor, Department of Fiqh \& Usü al-Fiqh, International Islämic University \\ Malaysia, sayedsikandar@iium.edu.my \\ Dr. Mohd Abbad Abdul Razak \\ Professor at International Islämic University Malaysia \\ maarji@iium.edu.my
}

\section{Abstract:}

Brain death as the modern medical criterion of death while a welcoming development for the twin purposes of saving medical cost and serving the demand for organ procurement is still a controversial subject in the field of Bioethics. The reason is that its scientific credibility in terms of conclusiveness of the termination of life of the whole body system is far from settled. Similarly, its compatibility with Islamic notion of death and its unique metaphysical criterion of the separation of the soul from human body is a debatable topic among the Muslim legislatures. In the Muslim debate what concerns us is the question of equating brain death to legal death. The most central issue in the juristic discourse is as to whether brain death is a definitive indicator that the soul has left the body. The answer has been divergent but with minimum discourse on both theological and scientific dimensions of the issue. Accordingly, this paper argues that interrogating the issue from scientific dimension would have resulted in a more informed verdict on the issue.

Keywords: brain death, equation, legal death, Muslim Fatwā

\section{Theoretical Framework}

Death in Islamic parlance signifies the separation of soul from body. ${ }^{1}$ The Qur'ān makes it clear," It is Allāh that takes the souls (of men) at death: and those that die not (He takes) during their sleep: those on whom He has passed the decree of death He keeps back (from returning to life) but the rest He sends (to their bodies) for a term appointed. Verily in this are Signs for those who reflect". ${ }^{2}$ The Prophet also has stated:" When the soul is taken, the eyes follow it.". However, since human soul being a metaphysical matter its true knowledge vests with God, ${ }^{3}$ hence, the precise determination of its exact precise moment of its departure from human body cannot be marked experimentally. Accordingly, classical Muslim jurists delineated the appearance/ observation of a number of 
physical signs by which, the advent of such happening can be legally presumed, in the case of both normal deaths and those of sudden demises.

With the advent of progress in medical science, a new criterion of death has emerged, namely the concept of 'brain death'. This development does not only change religious conception of death but is poised to overcome divergent views about other criteria as the true markers of death even among the scientific community. There were three dominant definition of death in the literature: first, biological, which considers death as the loss of physiological integrative unity of the bodya construct which provides the ratio legis for the advocates of brain death as a definitive sign of death at present. The reason is that the loss of the whole brain function immediately results in the loss of bodily integrity. Second, psychological which holds that death involves the permanent loss of consciousness or other essential human properties associated with personhood, thus becoming a logic for advocating, the loss of that part of the brain which affects the higher functions of human beings (neocortical brain death), such as thinking, reasoning and feeling. Third, sociological which regards death as the loss of societally conferred membership in the human community determinable by each societies definition of death. ${ }^{4}$

Subsequently, in the developed world, the theory of brain death as a modern criterion for death was medically inaugurated by the $\mathrm{Ad} \mathrm{hoc}$ Committee of the Harvard Medical School in August 1968. It considered brain death as a more adequate definition for death and characterized it as:1) unreceptivity and unresponsitivity; 2) no movement or breathing; and 3) no reflexes. ${ }^{5}$ While the advocates of whole brain death celebrate this determination as paradigmatic. Critics however, believe that the Ad hoc Committee in fact has not provided any conceptual definition for brain death as it neither defined brain death nor explained as to why the three signs are authentic markers of death. Nevertheless, the bottom line is that it has redefined death, and to the critics like Peter Singer, it has done so with two utilitarian purposes in perspective, namely to solve the problem of large number of brain death patients on respirators, and great need for their organs. Criticizing it, he held that "the Harvard Ad hoc Committee`s proposal marked a fundamental shift in our understanding of life and death. We could now take warm pulsating human beings, declare them dead and even cut out their hearts and other organs for transplantation purposes". 6 
The second milestone in the evolution of brain death was achieved by the conceptualization of "whole brain- standard" or" total brain death" (TBD) by the Commission constituted by President Carter in 1981. It held that such a state can be determined by: 1) irreversible respiratory and circulatory functions; or 2) irreversible cessation of all functions of the entire brain including the brain stem. Adopting this biological definition of death, the Commission argued that death is the moment when the body ceases to physiologically function and it is the brain on which all functions of an organism depend. And once the brain loses its somatic functions, it cannot be sustained indefinitely even with extra-ordinary medical care. Moreover, the Commission dismissed the ulterior motive of eyeing for vital organs for its recommendation, but instead it reasoned that the intention is letting dead body to be respected by removing life support from it thereby relieving the family members from looming uncertainty and supplying the scarce facilities at the intensive care for patients with reversible conditions. ${ }^{7}$

Resultantly, ever since 1981, most jurisdictions including some Muslim states, have adopted total brain death (TBD), which is (a neurological criteria), as the only medical and legal standard for death. However, at scientific plane, its finality has stirred heated debate among the scientific community in the West. For instance, one in three of nurses and doctors working with BD patients in one US hospital, Cleveland, believe that BD patients are dead because they either" were irreversibly dying" or "had unacceptable quality of life". Austriaco queries that if brain death is equal to legal death then why BD or TBD patients are not treated like a Cadaver by medical trainees to dissect and test the efficacy drugs on them. ${ }^{8}$

\section{Finality Debate in Science}

From bioethical perspective, the most resounding criticism of BD or TBD comes from Shewmon. He started his rebuttal of neurological criterion for death by challenging its two allegedly empirically proven signs, namely, cardiovascular instability of BD patients and loss of brainmediated integrative bodily functions- as brain is the central integrator of the body. ${ }^{9}$ To build up his case, first, he cited statistics of BD patients, obtained from professional publications and news reports and his own clinical practice with the contention that a BD patient inevitably is going to suffer cardiac arrest and whole-body system failure as sham. To him, out of $175 \mathrm{BD}$ patients, some survived longer than a month, a third longer than two months, seven survived longer than six months and four longer than one year. Accordingly, it is not the brain death which squarely marks the end of life but the process of brain damage inducing damage to the 
heart and lung which leads to the rapid death of the individual and not the brain alone. One specific worth mentioning among them is the case of TK. TK contacted meningitis at the age of 4, causing his skull bones to split. Multiple tests of his brain waves and the fact that he showed no spontaneous respiration or stem brain reflexes over 18 years were all testimony that he was dead(if we go by brain death as definitive marker of death). When he was transferred home, he was put on a ventilator; assimilated food put on his stomach tube, urinated spontaneously, overcame infections and healed wounds. To Shewmon, TK was dead at the age of 4 if we go by brain death equation that brain death means physiological instability thus end of life in an organism. TK's case practically defies this thesis as TK in spite of being considered death at the age of four, he at the time of research was 19 with stable physiological function, a condition much better than those of many ICU patients who are considered alive. ${ }^{10}$

Secondly, Shewmon rebutted the contention that BD patients lacking brain-mediated integrative functions are want of physiological function as a farfetched argument because there is a difference between brain-mediated function and somatically mediated function of human organs in the body. For instance, breathing if understood as moving of air in and out of the lung, it is brain mediated but if it is understood as respiration, which means exchange of oxygen and carbon dioxide, then it is somatically mediated function which is coordinated by the mitochondria of each cells in the human body and would not be disrupted by brain death. Similarly, if nutrition means eating food then it is brainmediated but if it is understood as the breakdown and assimilation of nutrient for energy and bodily structure, then it is somatic function which each cell performs in the body. Accordingly, BD patients can successfully assimilate energy, grow, attain sexual maturation even complete gestation; hence brain death does not impair failure of their entire system as supporters of brain death make us believe. ${ }^{11}$ Lastly, many living organisms like plants, flat warn, embryos and even adult humans do not necessarily need to have a central integrating organ. ${ }^{12}$

Concurring with Shewmon, Stuart Youngner and Robert Arnold, both Professors of Medicine at US Universities, concluded that: " Shewmon effectively argues that many of the body`s most important integrative functions are not carried out by the brain at all, and continue once the brain has ceased to function. He supports his argument with a plethora of clinical evidence and leaves [the supporter] of TBD in the 
untenable position of saying, "Oh, but we did not mean or care about those functions"'. ${ }^{13}$

Edward J. Furton, a Catholic Bioethicist, however, disagrees with Shewmon by grounding his arguments not on medical reasons but Catholic theology. First, human being is a composite of body and soul. Soul is an intellective or rational soul which is the source of integrative unity in human body. And medical science tells us that brain is the seat of cognitive life. Hence the unity between intellective soul and body is achieved and maintained by cognitive organ (brain), therefore, once the brain is dead, the soul has departed. ${ }^{14}$

Austriaco, considers Furton`s presupposition of the need for a biological organ to maintain the union between the body matter and the soul as a flawed interpretation of a bona fide metaphysical concept. Additionally, the assumption that whole brain is the seat of cognitive life is mistaken as it is the neocortex which is the locus of cognitive life. Moreover, he opines that Furton conclusion that TBD patients lose all brain functions is erroneous as clinically it is established that such individuals still retain some brain functions. For instance, clinicians have observed that $\mathrm{BD}$ patients frequently respond to surgical incision at the time of organ procurements with the significant rise in the heart rate and blood pressure-evidence of integrated neurological function at super spinal level. That is why Dr. Robert Turog has argued that "empirical work has shown that it is practically impossible to develop clinical tests that can determine that total brain function has been lost". ${ }^{15}$

To put the issue at its true perspective, Austiaco describes the existing approaches to $\mathrm{BD}$ as reductionist and mechanical. Instead, he argues for a holistic system perspective to the debate, calling it molecular integration. His main argument is that "...human body is a dynamic, complex and seamlessly integrated network not of organs nor of cells but of molecules... connected by reaction pathways that generate shape, mass, energy and information transfer over the course of human life" 16 . He dismisses brain death as an integrative organ between body and soul by maintaining that "it is the organization of molecules which would be a manifestation of immaterial soul. Human body receives it at fertilization and loses it when the molecule network disintegrates. Hence, coinciding with disintegration of molecular network that make up the body as a whole... which requires sporadic but system wide loss of cells". ${ }^{17}$ In sum, to Austriaco, the scientific rebuttal put forth by Shewmon against brain 
death as the only single marker of death but not a definitive sign as of 2003 has not been refuted by Western physicians.

\section{Legal Debate in Muslim Fatwa}

As we noted above that according to the classical Islamic legal outlook death signifies the departure of metaphysical soul from body. But since the nature and reality of the soul cannot be empirically determined, the jurists based their verdicts on the appearance of some obvious undisputed physical signs as the main criteria for its separation from the body. They are: "Cessation of breathing; sweating of the forehead; separation of feet from their arthroses; loss of feet reflexes in terms of pulling up and down; loosening of joints between arms and hands; bending of the nose towards right or left, and twists; disappearance of skin wrinkles; smoothening of facial wrinkles; caving in of temples; shrinking of men 's testicles; coldness of body; turning of feet and nose to blue; sharpening of the eyes; aloofness of lips; loss of the elderly`s eye blackness". ${ }^{18}$

It is on this account that classical jurists, insisted that since the appearance of these signs cannot occur immediately after the departure of the soul from the body, hence there is a need to delay burial of people with the history of passing out. For instance, Ibn Rūshd maintains:" Once a person is dead, his eyes should be closed and is recommended by the traditions of the Prophet that the arrangement for his burial should be hastened except if his body was salvaged after being drowned for fear of being in a state of coma whereby he may wake up after sometime. The same holds true for patients suffering from some ailments causing their sudden death such as those with conditions susceptible to cardiac arrest and others known to the physicians. That is why the physicians of our epoch have ruled that the burial of those relapsing to unconsciousness should be postponed for three days". ${ }^{19}$ Similarly al- Nawāwi holds that, " If there is any doubt as to the real death of the patient due to the fear of him being struck with apoplexy or panic thus rendering him motionless, then his burial should be delayed until the appearance of definitive signs of death on him, such as bad odor emanating from his body etc.. ${ }^{20}$

Nevertheless, with the intervention of medical technology to prevent some of the traditional signs of death, such as disruption of heart throb and respirations by putting a comatose patient in life support, the cautious approach adopted by classical Islamic law has come under intense scrutiny. Giving time and delaying a decision on such a patient's death is no longer an issue as his breath and blood circulation are maintained artificially. But what became an issue to modern medicine is as to how long such a medical intervention should be allowed to continue. The US Ad hoc Committee invented the idea of "brain death" as a 
medical criterion of death, thus stirring an ongoing debate about its

finality among the scientists and ethicists. Contemporary Islamic legal discourse also followed a bipolar approach with one difference that here unlike the Western debate the issue is one of legality rather than that of scientific finality.

The majority represented by the Islamic Juridical Council affiliated with Muslim League of Nations, in its $10^{\text {th }}$ gathering in 1987 ,accepted brain death as a new criterion for physical death of a patient but stipulated that it cannot be considered as legal death (Mawt Shärī) of the patient which hinge on the cessation of heart throb and respiratory function when it held:" It is permitted to remove life-support for a patient if his whole brain functions have irreversibly stopped as testified by three physicians. However, he cannot be considered dead until the complete cessation of the beating of his heart and respiration, The reason is that brain death alone is not sufficient to unequivocally tell us about the death of the patient with certainty". ${ }^{21}$ Concurring with these contemporary jurists like, Jadd al-Haqq the former Shaikh of Azhar, argued:" Death does not occur except after the cessation of all life signs. For instance, brain death patient still breathe (though artificially), his heart throb and blood circulation are intact. Furthermore, such a patient lacks physical signs of real death as described by the jurists. Hence, brain death which is based on detection of electric waves (to determine functioning of brain) is not among what the jurists have outlined as a marker of death". ${ }^{22}$ Joining him, Sa id Ramadan al-Buti, also maintains that the legally valid signs('lamat al-mu'tabarah li al-mawt shar'an) of death are:" the cessation of heart throb and its complete stoppage; brain death is based on medical criteria and not Shari criteria; returning of a brain death patient to life is neither impossible rationally nor from the Shar $i$ standpoint; the original presumption about the existence of life in brain death patient is stronger than medicinal indicator about his death; and hence not considering brain death patient as legally death can thwart the possibility of declaring a salvageable patient as dead(sadd alDhari $a h)^{\prime \prime} .23$

Other individual jurists are more critical of this equation. For instance, Ibn Baz specifically expressed his skepticism on the equation of brain death to legal death, when he ruled, in response to his interlocutor, saying:" Mere declaration of brain death does not amount to legal death of the patient unless the sure signs of death are present on him. Hastily rushing to the conclusion of a brain death patient as being legally dead would allow physicians to cut his body parts for medical use and tamper with fresh human corpses". ${ }^{24} \mathrm{He}$ also disagreed with medical decision of considering brain death as irreversible in view of the documented 
noticeable number of brain death patient having been waken up later on. ${ }^{25} \mathrm{Al}$-Ammari was more conscious of the scientific side of the debate among Western scholarship over the matter when he held:" We cannot say for sure that a brain death patient is not legally still alive. The best that we can describe his condition is like that of a dying person but not legally dead unless the juristic signs of death set on him. Hence, medical declaration of brain death patient to us only amounts to considering a patient about whose recovery we cannot hope". ${ }^{26}$ Abu Zaid presumes that the existence of soul in the body means that all human organs are alive (function) and hence death means the loss of the entire bodily organs functions and not just the loss of the function of the brain". ${ }^{27}$

In maintaining so, they supported their stand by arguing: first, the loss of consciousness cannot be a definitive sign of death especially if it is for a short duration. According to Qur ānic account, the Companions of Cave ( Ashab Kahf) went into a state of long sleep for more than three hundred years and then woke up and continued their lives. ${ }^{28}$ Second, the truth that factual existence of the life of a human being cannot be denied unless there are definitive signs/reasons to the contrary is an established principle in Islamic law on the authority of the legal maxims: 'Certainty cannot be removed by doubt'; and 'The basic presumption about the continued existence of original state unless there is a concrete proof to the contrary.' Hence, brain death being not a definitive criterion does not negate the continued existence of a patient's life. Lastly, the preservation of human life as one of the topmost objectives of Islamic law demands non-recognition of brain death as a decisive factor in the determination of a patient`s legal death". ${ }^{29}$

Conversely, another body of opinion represented by the Islamic Juridical Council affiliated with OIC considered brain death as a definitive criterion of death when it held:" A brain dead patient can be considered legally dead if two signs are present in him: first, based on physicians' opinion, his heart beat and respiration have irreversibly stopped; second, he has lost all functions of his brain irreversibly, on top of his brain starting to decompose. ${ }^{30}$ Concurring with this, al-Ashqār says that based on traditional criterion, once a patient's heart stops beating regardless of the circumstances, on life support or not, he is considered dead even if his kidneys still function. Hence, a brain dead patient satisfies this criterion. ${ }^{31}$ Likewise, Muhammad Ali al-Bar held that brain death replaces the cessation of heart as a new criterion for the purpose of declaring a patient as legally dead (mayyit shar 'än). Once such a state is diagnosed in a patient and attested by consensus among a panel of physicians, he should be pronounced as dead. ${ }^{32}$ More pronounced position 
of acceptability was adopted by Muhammed Yāsīn who declared that:" The argument that the loss of brain function does not mean the loss of all the functions of body system in humans is invalid. I am of the view that the mere fact that the heart of a brain death patient still beats or his kidneys are potent, or some other of his bodily organs still function, do not indicate the presence or absence of the soul in his body. As some of these organs may function whether the person still has the soul or not. Therefore, the decisive factor for fulfilling the Islamic criterion of separation of soul from the body is the brain death. ${ }^{33}$

To support their position, they argued: first, the fact that the brain dead patient shows some bodily functions does not qualify him as being considered legally alive. His case is similar to the case of a new born who does not make a cry after birth even if he moves or urinates, he will still be treated as being born dead according to Imām Mālik. Second, analogous to the case of not considering the killing a human being whose stomach was ruptured by another resulting in the protruding of his intestines, as murder because the victim had no stable life when the assailant attacked him. Similarly, a brain dead patient has no stable life even if some of his body parts are still functioning. ${ }^{34}$ Additionally, they rebutted the arguments by the majority by holding: first, the anecdote of the Companions of the Cave was not a case of clinical comatose but a normal condition of sleep and a miracle from God which cannot be used as a legal evidence. Second, the presumption of continuation of life in the case of a brain death patient is sufficiently rebuttable by the testimony of physicians to the effect of him to be dead on account of the death of his brain. ${ }^{35}$ Third, even traditional criteria, namely cessation of respiration and cardiac arrest do not suffice as indicators of the cessation of all signs of life. Some signs like growth of hair and nail continue for some time even after cessation of heart beat and respiration as the traditional criteria of death. Fourth, artificially maintaining a lifeless body (after brain death) does not put a patient on the same footing as the person who breathes naturally. Fifth, the claim that jurists prescribed the cessation of heart beating as a definitive sign of death is not authentic. Lastly, the contention that a brain death may return to life also cannot hold true for traditionally declared death individuals. Nevertheless, they concede the fact that whether the brain death criterion really serves as a definitive evidence of rebutting the original presumption of the life-continuity (istishab al-hayat) in a patient, needs to be investigated further. Similarly, the fear of abuse in circumstances where a patient's life could be expedited by using brain death criteria if warranted, caution would be needed not to depend upon it. $^{36}$ 
However, the majority refuted their analogy of brain dead with that of a baby born as dead as it was a disputed case among the jurists themselves; majority considered such a baby as being born alive and then having passed away, for the purpose of observing religious ritual of burial for such an infant. They also held that their example of murder victim cannot build a case for brain death as the said victim, at best was, 'the case of a dying person' and not a dead person. ${ }^{37}$

Other scholars when engaging with the issue have taken the position of the non-equation. For instance, disagreeing with the adoption of medical definition of death as the main determining test for declaring a patient death, Kasule a medical expert and an authority on Islamic biomedicine, maintains: "brain death in medicine is a matter of degree, whole, lower and higher brain death all of which are still debatable as far as they do not define the exact time of death (which is within the will of God). Therefore, one cannot with certainty subscribe to it". ${ }^{38}$

Concurring with Kasule, other researchers like Pandela et al, advance the view that the standard setting verdict by the Juridical Council based in Jiddah pertaining to brain death not only has ignored the traditional signs of death as delineated by the classical jurists but also does not reflect deeply on the Western medical definition of brain death when adopting it in its entirety. The verdict in question has failed to detail several issues including: first, while medical discourse on brain death has triggered debate about whole brain death and brain stem cell death and other levels of brain failures among medical experts and ethicists, the Council has adopted a less rigorous test. Similarly its qiyas(equation)between the life of a brain death patient and that of a beheaded victim is problematic as in the latter case, the person has lost his whole brain but medical test of brain death does not concern itself with the question of total brain failure. Second, it also has not addressed itself to the question of quantifying the irreversibility of brain functions as cases of brain death patients returning to life are clinical realities. ${ }^{39}$ Third, the council's stipulation that brain death is a conclusive evidence of the patient's death when it starts degeneration is unrealistic because standard brain death test is not concerned with such an additional sign. Finally, the Council also does not address the most fundamental question in this context as to whether physician's attestation of death has the effect of his declaration pertaining to the departure of the soul from the body as well.

Juxtaposing the medical definition of death with that of classical diagnostics which makes it certain even to the nicked eyes that a 
patient has deceased, Birgit Krawietz believes that at the heart of ethical debate regarding clinical definition of death with its multiple implications for the deceased, his relatives and medical care givers lies on the question of "who determines the moment of death", which Muslims believe to be within the province of God's Knowledge and Power. ${ }^{40}$

In short, it is clear that the supportive view taken on this issue by the Jiddah based juristic council, has not only addressed the scientific validity of the finality claim about brain death, but also has failed to scrutiny theologically as to whether brain death can measure the exact moment when the angel takes a human soul away as directed by God according to Islamic tenet.

\section{Critical Evaluation}

In the light of the above analysis, it is crystal clear that the scientific aspect of the debate over the issue of brain death as the main criterion of death has not been sufficiently appreciated particularly by both bodies of the juristic discourse on brain death. For instance, the opponents` equation of brain death with legal death while conceding that such an equation is not allowed yet fall into the argument of equation when they stipulated that provided that the brain death results in the irreversible cessation of blood circulation and respirator function. They were unaware that the idea of total brain death presupposes such conditions. On the positive side, however, some individual jurists like Ibn Baz and 'Ammari have made scientifically inspired stand when they point to clinical evidences proving the fallacy of brain death as a decisive marker of death.

The least informed view of scientific argument on brain death was expressed by the supporters. Their argument is nothing but a replication of what the US Ad hoc Committee held on brain death criterion as the true determiner of death. Some like Yāsīn was so rhetorical that he went to the extent of quantifying the metaphysical issue of the separation of the soul from the body, without trashing out the theological discussion that the knowledge of separation of soul from body is beyond materialistic estimation. Kasule, a scientist himself, made the issue cardinally explicit.

Accordingly, we are of the view that had the Islamic discourse of Islamic legal verdict (fatwa) on equating brain death with legal death (mawt shar i), enriched its analysis of the issue by reflecting on the scientific side, its conclusion would have been more immune against criticism. It could do so by taking into account the following: 
1. Interrogating the concept of total brain death theory itself on the basis of the scientific fact and clinical reports that a brain death patient does not lose all of his brain functions. The reason is that during organ procurement from clinically declared dead (brain death patient), it responds to surgical incision and his blood pressure and heart rate rise;

2. Questioning the brain death theory on account of reported cases of survival after the dead pronouncement, for a considerable amount of time, by maintaining that brain death alone is not the immediate and instant marker of legal death unless it induces damage to other vital organs of life, which supports the classical views of delaying a decision until the signs of decay and decomposition take effect in the body;

3. Understanding the meaning of irreversibility of blood circulation and respiratory function which constitute the backbone of brain death theory in science, as explained by Shewmon, provides a cogent argument against brain death as the sole marker of death. To him, respiration being a process of exchange between oxygen and carbon dioxide is a somatically mediated function which requires not merely the death of the brain but the death of the mitochondria of each cells; and

4. Probing the validity of the scientific proposition that not only the damage of the cells but the disintegration of molecule networks is necessary so as to avoid the desecration of pulsating bodies for organ transplantation and hastening the burial of potentially resuscitable brain death patients which classical Islamic law was articulating.

\section{Conclusion}

By looking at strong medical arguments against brain death as the sole determining factor of real death, and prohibitive stand by some contemporary jurists and even the cautious permissible positions by the supporters, one may observe that given enough time for a brain death patient, except if he has made a will to donate his organ, to start degenerating by observable traditional signs of death as outlined by classical jurists would go a long way in ethical management of end-oflife pronouncements. That is why classical jurists were well aware of ethical risks in setting any easy single criterion for death. For instance, Imām Shāfî, held that it is prudent not to hasten in the funeral management of the person who suddenly dies without being sick as he might have had a heart attack. He should be left for two or three days so 
as his body starts decaying as he might have gone into a state of unconsciousness (mughmā 'aläyhi). ${ }^{41}$ Ibn Qudmā'h, also stated that: "It is recommended that funeral arrangement for a dead should be expedited if his death is certain. But if there is any shred of doubt about his death with certitude then delaying is better until the physical signs of death appear on him. But anyone who dies suddenly because of fear of war or beast or fall from the mountain, his burial should be deferred until the appearance of death signs on him". ${ }^{42}$ Accordingly, Muslim contemporary fatwa by enriching its debate on the scientific dimension of brain death as discussed in this paper would have achieved better integration of classical Islamic law with modern medicine on top of leaving the matter of metaphysics to God.

\section{Bibliography}

1. Al-Daīirī Zaid Nawāf. "Majma Buhūth Fiqhiyyah.Amman: Dar Yafa alIlmiyya'h., Berut, Lebanon, (2007).

2. Al-Nawāwī, Yahayāā Ibn Sharaf. Rawḍat al-Ṭalibīn. Beirut al-Maktab al-Islāmī, (1991).

3. Ahmad,Wahaj.D. “ An Islamic View of Death and Dying” (1997)

4. Anas, Muhammad.(n.d). Faith and Cultural Aspects of Grief, Bereavement and Dying: An Islamic Perspective, at samaa.org.au/home/wp-content(accessed 8 October 2017).

5. Abu Zaid, Bakr ibn Abd Ullāh.(1996). Fiqh al-Nawāzil. Beirut: Mu`assisat alRisalah.

6. Al- Ashqār, Muhamamd Sulaiman.(1991). "Nihayat al-Hayat" in Nadwat alHayat al-Insan: Bidyatuha wa Nihayatuha fi alMafhum al-Islami. 14 April 1987, al-Munazzimah al-Islamiyyah li al-Ulum al-Tibbiyyah. Kuwait.

7. Al-Ammari, Abd al-Qadir Muhammad.(1991). "Nihayat al-Hayat" in Nadwat al-Hayat al-Insan: Bidyatuha wa Nihaya'h fi al-Mafhum al-Islami. 14 April 1987,al-Munazzimah al-Islamiyyah li al-Ulum al-Tibbiyyah. Kuwait.

8. Al- Hajīrī, Hamad Muhammad. (2006). "Mawt al-Dimagh Bain al-Fuqaha wa al-Atibba," Majallāh Kulliyyat al-Shari`ah wa al-Dirasat al-Islamiyyah,

9. Austriaco, Nicanor, "Is brain-dead patient really dead?" St. More, (2003).

10. Mujallah al- Buhūth al-Islamiyyah,

11. Munazzamat al-Mu`tamar al-Islami.(1998).Qararat wa Tawsiyyat al-Majma`alFiqh al-Islami. Jiddah: Dar al-Qalam.

12. Padela, Aasem I \& Qureshī Omar.(2016).” Islamic Perspectives on Clinical Intervention Near the end-of-life, we can but must we? ", Medical Health, Care and Philosophy, at https:// www. researchgate.net/. ../307978967. Islamic perspectives on clinical intervention (accessed 10 July 2017).

13. Patel Ahsfaq, Death and Dying- A Final Journey: An Islamic Perspective(n.d), at. slideplayer.com/slide/3779119/ (accessed 28 September 2017)

14. Shiekh, Aziz.(1998). Death and Dying- A Muslim perspective, Journal of the Royal Society of Medicine, Vol.91, pp.139-140.

15. Singer Peter "Rethinking of Life and Death: The Collapse of Our Traditional Ethics" New York. St. Martin`s Press, (1994). 
16. Ibn Rushd, Muhammad ibn Amad.(1983). Bidayat al-Mujtahid, Beirut: Dar al-Kuatab al-Islamiyyah,

17. Ibn Qudmā'h, Abdullāh Ibn Ahmad, Al-Mughni , Vol.3, Cairo: Dar Hijr, .(1992)

18. Ibn Baz, Abd al-Aziz.(2000). Majmu` Fatwa wa Mawalat Mutanawi`ah, Muhmmad Sa ād al-Shuwi ir (ed). Jiddah: Ri`asat al- Buhūth al-'Ilmiyyah wa al-Ifta.

19. Yāsīn, Muhammad Na`im, (1991). “ Nihayat al-Hayat al-Insaniyyah fi daw`I Ijtihadat al-Umala al-Muslimin wa al-Mu tiyat al-Tibbiyyah" in Nadwat alHayat al-Insan: Bidyatuha wa Nihayatuha fi al=Mafhum al-Islami. 14 April 1987,al-Munazzimah al-Islamiyyah li al-Ulum al-Tibbiyyah Kuwait.

\section{Note \& References}

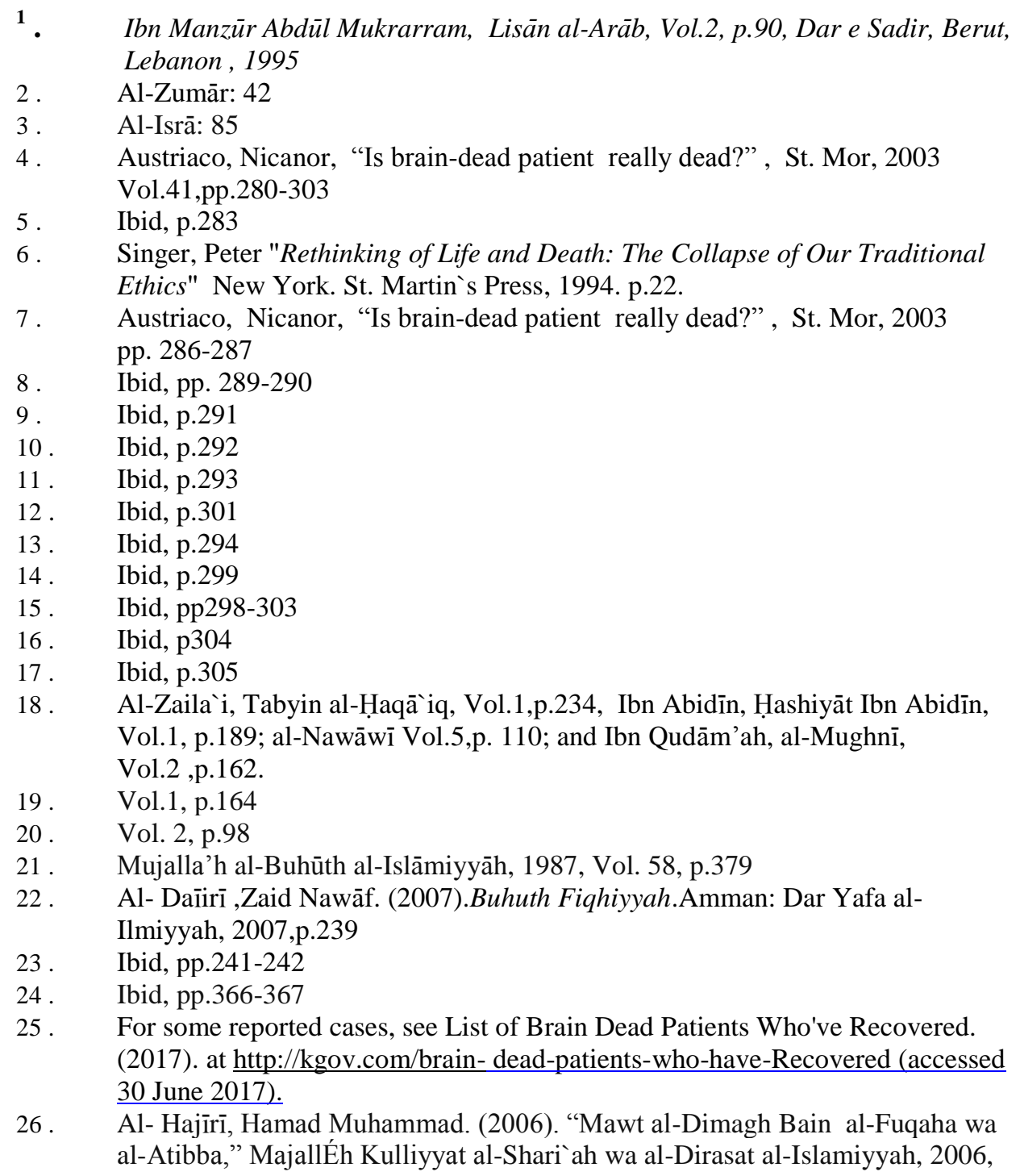


p. 486

27. Abu Zaid, Bakr ibn Abd AllÉh.(1996). Fiqh al- Nawāzil. Beirut: Mu`assisat alRisalah, 1966:Vol.1, p.222

28. Al-Kahf: 9-12

29. Al-Hajīīi, 2006, pp.318-319

30. Al- Hajīīi, 2006, p.320

31. Al- Ashqār, Muhamamd Sulaiman.(1991). "Nihayat al-Hayat" in Nadwat alHayat al-Insan: Bidyatuha wa Nihayatuha fi al=Mafhum al-Islami. 14 April 1987, al-Munazzimah al-Islamiyyah li al-Ulum al-Tibbiyyah. Kuwait. p.349

32. Al- Daïirī, 2007, p.244

33. Yāsīn, Muhammad Na `im. " Nihayat al-Hayat al-Insaniyyah fi daw`I Ijtihadat al-Umala al-Muslimin wa al-Mu`tiyat al-Tibbiyyah" in Nadwat al-

Hayat al-Insan: Bidyatuha wa Nihayatuha fi al=Mafhum al-Islami. 14 April 1987,al-Munazzimah al-Islamiyyah li al-Ulum al-Tibbiyyah. Kuwait, (1991). P. 424,19

34. Al- Hajīīī, 2006, p321

35. Ibid, pp.319-321

36. al- Daīirī, 2007, p.245

37. Al- Hajīīi , 2006, pp.318-321

38. Kasule. n.d

39. Pandela, Aasem \& Qureshī Omar.(2016). "Islamic Perspectives on Clinical Intervention Near the end-of-life, we can but must we? ", Medical Health, Care and Philosophy, at https:// www.researchgate.net/ .../307978967_Islamic perspectives on clinical intervention (accessed 10 July 2017)

40. Krawietz, 2003

41. Al- Nawāwī, Yahaya Ibn Sharaf.().Rawdat al-Talibin.Beirut al-Maktab alIslami, 1991, vol.3,p.110

42. Ibn Qudmah, Abdullah Ibn Ahmad. Al-Mughni, Cairo: Dar Hijr, Egypt, 1992, Vol. 2, p.162 